\title{
Performance of Spodoptera frugiperda (Lepidoptera: Noctuidae) Fed on Six Host Plants: Potential Risks to Mid-high Latitude Crops in China
}

\author{
Yu Chen ${ }^{1}$, Jingfei Guo ${ }^{1}$, Zupeng Gao ${ }^{1,2}$, Kanglai $\mathrm{He}^{1}$, Shuxiong Bai ${ }^{1}$, Tiantao Zhang ${ }^{1} \&$ Zhenying Wang ${ }^{1}$ \\ 1 State Key Laboratory for Biology of Plant Diseases and Insect Pests, Institute of Plant Protection, Chinese \\ Academy of Agricultural Sciences, Beijing, China \\ 2 Engineering Research Center of Natural Enemy Insects/Institute of Biological Control, Jilin Agricultural \\ University, Changchun, China \\ Correspondence: Zhenying Wang, State Key Laboratory for Biology of Plant Diseases and Insect Pests, Institute \\ of Plant Protection, Chinese Academy of Agricultural Sciences, Beijing 100193, China. Tel: 86-10-6281-5945. \\ E-mail: zywang@ippcaas.cn
}

Received: July 22, 2020

Accepted: August 25, 2020

Online Published: September 15, 2020

doi:10.5539/jas.v12n10p16

URL: https://doi.org/10.5539/jas.v12n10p16

\begin{abstract}
The fall armyworm, Spodoptera frugiperda (J. E. Smith) (Lepidoptera: Noctuidae), is a polyphggous and widespread insect pest. In the study, the biological characteristics and nutritional indices of S. frugiperda fed on six crops, namely corn, sorghum, wheat, soybean, peanut, and cotton, were investigated under laboratory conditions. These crops are cultivated mainly in the mid-high latitude of China. Results showed that $S$. frugiperda was able to develop and reproduce on all six tested plants. Larvae reared on corn exhibited a significant shorter larval and pupal duration, higher pupal weight, and higher fecundity, which were $16.2 \mathrm{~d}, 8.9 \mathrm{~d}$, $0.248 \mathrm{~g}$, and 979.4 eggs per female, respectively. The host plant significantly affected relative growth, consumption, and metabolic rates, as well as other nutritional indices. Biology and nutritional indexes suggested that corn was the most suitable host. Besides, peanut, sorghum, and wheat have also been shown to be the suitable hosts for $S$. frugiperda. Although cotton and soybean were found to be less adequate, high larval and pupal survivors recorded on cotton and soybean leaves have indicated that damage may occur in these plants. This work reveals the damage risk of potential hosts of $S$. frugiperda, lays the foundation for the design of pest management strategies.
\end{abstract}

Keywords: fall armyworm, Spodoptera frugiperda, biology, nutritional index, food consumption

\section{Introduction}

The fall armyworm, Spodoptera frugiperda (J. E. Smith), is an important polyphagous pest native to tropical and subtropical regions of the Americas (Sparks, 1979; Nagoshi et al., 2017). It is widely distributed throughout the United States, Puerto Rico, Mexico, Brazil, and Argentina (Clark et al., 2007). In January 2016, S. frugiperda was detected in western Africa (Goergen et al., 2016; Nagoshi et al., 2018). In May 2018, this pest was discovered in southwest India (Sharanabasappa et al., 2018). In January 2019, S. frugiperda was first observed in Yunnan Province, southwest of China, and subsequently invaded 26 different provinces except for Xinjiang, Qinghai, and northeastern China (Guo et al., 2018; Jing et al., 2020). So far, S. frugiperda has been confirmed in eastern and southern Asian countries (Sun et al., 2019; Li et al., 2020).

S. frugiperda is commonly referred as the corn (C) strain, and the rice (R) strain (Quisenberry, 1991; Nagoshi \& Meagher, 2004). The caterpillars of S. frugiperda can damage over 350 plant species, causing severe yield losses in many economic crops, especially corn (Zea mays L.), rice (Oryza sativa L.), soybean (Glycine max (L.) Merrill) and cotton (Gossypium hirsutum L.) (Nagoshi, 2009; Bueno et al., 2011; Montezano et al., 2018; Guo et al., 2020). This pest causes damage on corn with average losses of $26.6 \%$ in Ghana and $35 \%$ in Zambia (Day et al., 2017), and reduced grain yields of up to 55\% and annual losses of US \$ 400 million (Lima et al., 2010).

Necessary biological studies on the consumption and utilization of different host plants are essential to address the effects of the nutritional composition of different plants on the pest (Scriber \& Slansky, 1981; Barros et al., 2010). Host plants can affect the life history of insects in many ways, including development, survivorship, 
reproduction, and longevity (House, 1961; Meagher \& Nagoshi, 2004). The food ingested by insect herbivores undergoes digestion, and the energy transformed it into body substance. The investigation on the utilization of host by insect becomes significant as it gives indirect measurements of relative susceptibilities and attributes of the host plant to insect performance and infestation (Slansky, 1990).

Studies on food utilization and consumption of insect are critical in understanding the interaction between insects and plants and also in helping to plan pest management strategies by providing estimates of potential economic losses (Ramalho et al., 2011) and improving insect mass rearing techniques (Souza et al., 2001; Busato et al., 2002). Recently, numerous researches on biology and nutrition have been carried out. The focus of these studies was based on different varieties of the same crop (Naseri et al., 2010; Rosa-Cancino et al., 2016; Barcelos et al., 2019), genetically-modified plants (Ramalho et al., 2011; Sousa et al., 2016), or artificial diets (Pinto et al., 2019; Truzi et al. 2019). Less research compared the life parameters among different hosts. Field surveys found that $S$. frugiperda caused damage on corn, wheat, sorghum, and peanut in China (Jiang et al., 2019). Though the infestation was not detected on soybean and cotton in China at present, S. frugiperda is becoming an important pest to cotton and soybean, which were grown on a large scale in the Brazilian Cerrado (Barros et al., 2010).

Therefore, this study aimed to assess the biology and nutrient indices of $S$. frugiperda larvae feeding on corn, soybean, sorghum (Sorghum bicolor (L.) Moench), wheat (Triticum aestivum L.), peanut (Arachis hypogaea L.) and cotton, which were the most important economic crops in China, in order to reveal the damage risk of potential hosts of $S$. frugiperda.

\section{Methods}

\subsection{Insect Stocks}

A colony of S. frugiperda was initially collected and identified from a corn field in Mangshi, Yunnan Province, China, and maintained in the laboratory for five to six generations. They were reared under laboratory-controlled conditions (temperature of $26 \pm 1{ }^{\circ} \mathrm{C}$, relative humidity of $60 \pm 10 \%$, photoperiod of $16 \mathrm{~h}$ light $/ 8 \mathrm{~h}$ dark) and fed on a regular artificial diet.

\subsection{Plant Material}

For the treatments, leaves of corn ('Zhengdan 958' cultivar), sorghum ('Liaoza 11' cultivar), wheat ('Zhongmai 9' cultivar), soybean ('Wandou 28' cultivar), peanut ('Zhonghua 5' cultivar), and cotton ('Shiyuan 321' cultivar) were used. About 30 seeds were sown in a plastic pot $(\mathrm{L} 60 \times \mathrm{W} 50 \times \mathrm{H} 50 \mathrm{~cm})$ and cultivated in a greenhouse $\left(24.0 \pm 1{ }^{\circ} \mathrm{C}, 50-70 \%(\mathrm{RH})\right.$ and photoperiod $16: 8 \mathrm{~h}(\mathrm{~L}: \mathrm{D})$. When plants grew up to three or four leaves fully expanded, they were used for larvae rearing.

\subsection{Biological Parameters Assay}

Experiments were carried out in environmental chambers (Heraeus Group, HPS 500, Germany) under controlled conditions $\left(26 \pm 1{ }^{\circ} \mathrm{C}, 60 \pm 10 \% \mathrm{RH}\right.$ and hours of photoperiod, $\left.16 \mathrm{~L}: 8 \mathrm{D}\right)$. The newly hatched larvae $(<24 \mathrm{~h})$ were selected and placed individually in Petri dishes $(6 \mathrm{~cm}$ diameter $\times 1.5 \mathrm{~cm}$ height). Leaf discs (about $1 \mathrm{~cm}$ in diameter) from each host plant were offered as food sources for larvae and replaced on a daily basis to avoid excessive water loss. There were six replicates for each crop and 60 larvae per treatment to record the data of larval and pupal stage.

After the emergence of the adults, one pair of male and female moths, which had emerged on the same day, were moved to a transparent cylindrical PVC cage $(15 \mathrm{~cm}$ diameter $\times 30 \mathrm{~cm}$ height $)$. The cage was lined with a paper sheet to collect eggs, and the top was covered with double-deck gauze to avoid adult escape. Adults were fed with a $10 \%$ honey-water mixture on a piece of soaked cotton packed inside a Petri dishes. There were 20 replicates (20 PVC cages) for each treatment.

The following biological parameters were evaluated: larval duration, larval survivorship, pupal duration, pupal weight at $24 \mathrm{~h}$, pupal survivorship, the female fecundity (eggs/female), and longevity of male and female adults.

\subsection{Nutritional Indices Assay}

Since the first-third instar larvae of $S$. frugiperda are too light to weigh, fourth instar larvae were weighed precisely to investigate the effects of different host plants on the nutritional physiology of $S$. frugiperda. Experiments were carried out in environmental chambers (Heraeus Group, HPS 500, Germany) under controlled conditions $\left(26 \pm 1^{\circ} \mathrm{C}, 60 \pm 10 \% \mathrm{RH}\right.$ and hours of photoperiod, $\left.16 \mathrm{~L}: 8 \mathrm{D}\right)$.

Newly hatched larvae $(<24 \mathrm{~h})$ were maintained on leaves of each host plant up to the fourth instar stage. Then, the fourth instar larvae $(<12 \mathrm{~h})$ were selected, without feeding for $24 \mathrm{~h}$ to clear the intestinal tract, and weighed by using an analytical balance (Shimadzu/Toledo AY220) accurate to 0.0001 grams. Twenty larvae were used for 
each host plant (independent replicates). The larvae were individually isolated in Petri dishes $(6 \mathrm{~cm}$ diameter $\times$ $1.5 \mathrm{~cm}$ height) lined with moistened filter paper and fed plant leaves of a single landrace on three consecutive days. Host leaves were replaced daily. After the experiment, the larvae, remaining leaves, feces were separated, weighed, and dried in an oven at $60{ }^{\circ} \mathrm{C}$ for $72 \mathrm{~h}$ until reaching a constant weight and then were weighed. At the same time, fresh and dry weights of 10 larvae were recorded to obtain the correction factor for initial dry weight. The water loss of the host leaf was calculated similarly to the water loss of the larvae.

From these data the weights were obtained: food ingested (I), feces (F), larvae weight gain (B), larvae mean weight $(\mathrm{C})$, and the duration of feeding time $(\mathrm{T})$. Then the nutritional indices were calculated as follows: food metabolized $(\mathrm{M}=(\mathrm{I}-\mathrm{F})-\mathrm{B})$, the relative growth rate $(\mathrm{RGR}=\mathrm{B} /(\mathrm{C} \times \mathrm{T}))$, the relative consumption rate $(\mathrm{RCR}=$ $\mathrm{I} /(\mathrm{C} \times \mathrm{T}))$, the relative metabolic rate $(\mathrm{RMR}=\mathrm{M} /(\mathrm{C} \times \mathrm{T}))$, the efficiency of conversion of ingested food $(\mathrm{ECI}=$ $(\mathrm{B} / \mathrm{I}) \times 100)$ and digested food $(\mathrm{ECD}=(\mathrm{B} /(\mathrm{I}-\mathrm{F})) \times 100)$, the approximate digestibility $(\mathrm{AD}=((\mathrm{I}-\mathrm{F}) / \mathrm{I}) \times 100)$, weight of the assimilated food (I - F) (Waldbauer, 1968; Scriber \& Slansky, 1981).

\subsection{Statistical Analysis}

Effects of host plants on biological characteristics (duration, pupae weight, survival, female fecundity, and adult longevity) of $S$. frugiperda were analyzed with one-way analysis of variance using the generalized linear model (PROC GLM, SAS V9.4) (Zhao et al., 2014). Prior to analysis, all data were checked for normality and homogeneity of variances using the Kolmogorov-Smirnov (Kolmogorov, 1933; Smirnov, 1939) and Levene's test (Levene, 1960). The percentage survivorship was normalized using the transformation $y=$ arsine $(\mathrm{x} / 100)^{1 / 2}$. Nutritional parameters were subjected to one-way ANOVA using the $F$-test (Fite et al., 2018). Treatment differences among means were compared using Tukey's multiple range tests. Statistical analyses were performed using SAS software (SAS Institute Inc., Cary, NC, USA). Graphs were generated using GraphPad Prism 5.0 (GraphPad Software, Inc., San Diego, CA). All data are calculated as Means \pm standard error.

\section{Results}

\subsection{Growth and Development}

The host plant had a significant impact on the growth and development of S. frugiperda. The larval duration was the shortest for $S$. frugiperda fed on corn leaves, and longest on peanut and soybean, while the other treatments did not differ between themselves $\left(F_{5,320}=27.72, P<0.001\right.$, Figure 1). The larval duration was 2.9, 3.6, 5.1, 4.5, and 4.0 days shorter for corn when compared to the larval duration fed on sorghum, wheat, peanut, soybean, and cotton, respectively. The pupal duration was shorter when $S$. frugiperda fed on grasses (corn, sorghum, and wheat) than those fed on soybean, peanut, and cotton $\left(F_{5,319}=7.76, P<0.001\right.$; Figure 1$)$. 

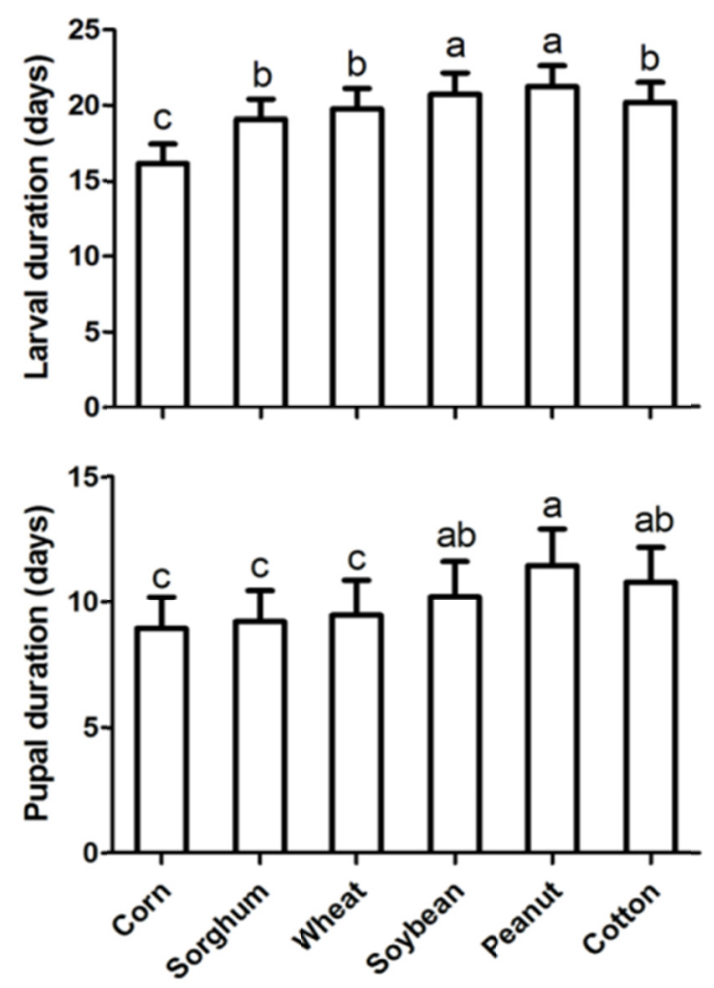

Figure 1. Larval and pupal duration (Mean $\pm \mathrm{SE}$ ) of Spodoptera frugiperda fed on six different host plants Note. Different letters indicate significant differences $(P<0.05)$ by using Tukey's multiple range tests, the same as below.

The pupal weight was also significantly affected by the host plant $\left(F_{5,319}=9.30, P<0.001\right.$; Figure 2$)$. The peanut and corn possessed the highest pupal weight among the treatments, which was 0.253 and $0.248 \mathrm{~g}$, respectively. The lowest pupal weight was observed when larvae fed on cotton, which was about $0.200 \mathrm{~g}$.

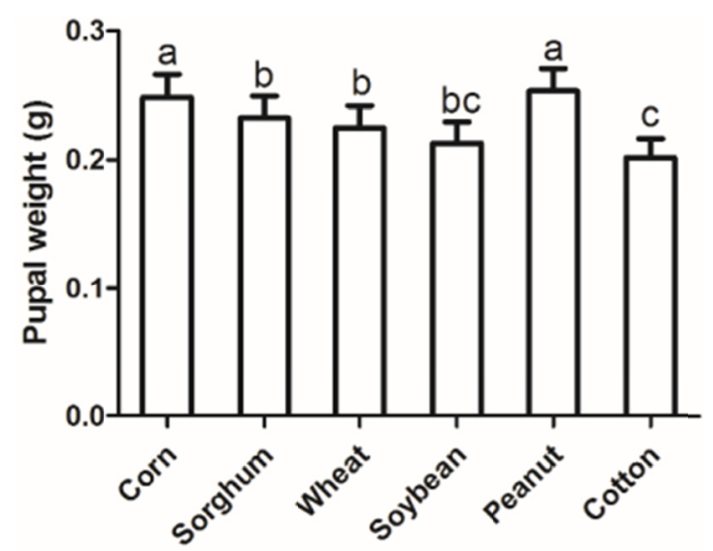

Figure 2. Pupal weight (Mean \pm SE) of Spodoptera frugiperda fed on six different host plants

Survivors of $S$. frugiperda larvae and pupae fed on six plants ranged from $87 \%$ to $95 \%, 90 \%$ to $96 \%$, respectively, and no significant difference was foundbetween treatments $(P>0.05$, Figure 3). 

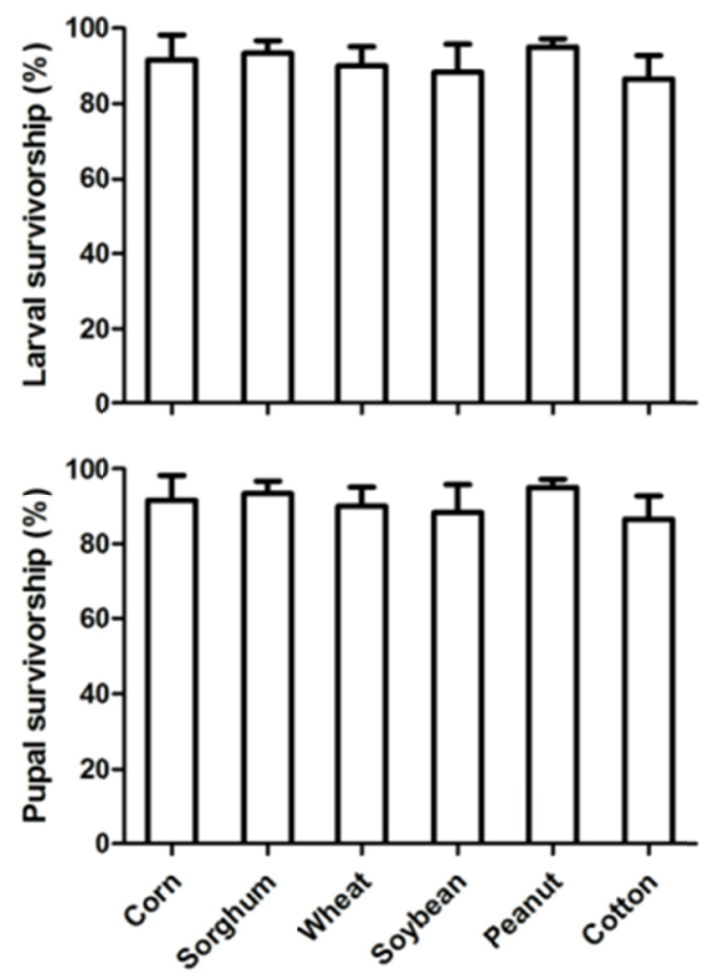

Figure 3. Larval survivorship and pupal survivorship (Mean \pm SE) of Spodoptera frugiperda fed on six different host plants.

Although there were no significant difference in female $\left(F_{5,114}=0.86, P=0.322\right)$ and male longevity $\left(F_{5,114}=\right.$ $0.54, P=0.645$ ), the longevity of female was about 1.5 days longer than male adult (Figure 4$)$. The number of eggs per female was significant influenced by host plant $\left(F_{5,114}=21.25, P<0.001\right)$. Higher amounts of eggs/female were found in peanut and corn, reaching around 1000 eggs/female. The fecundity was significantly lower for females reared on cotton, which was 683 eggs/female (Figure 5).

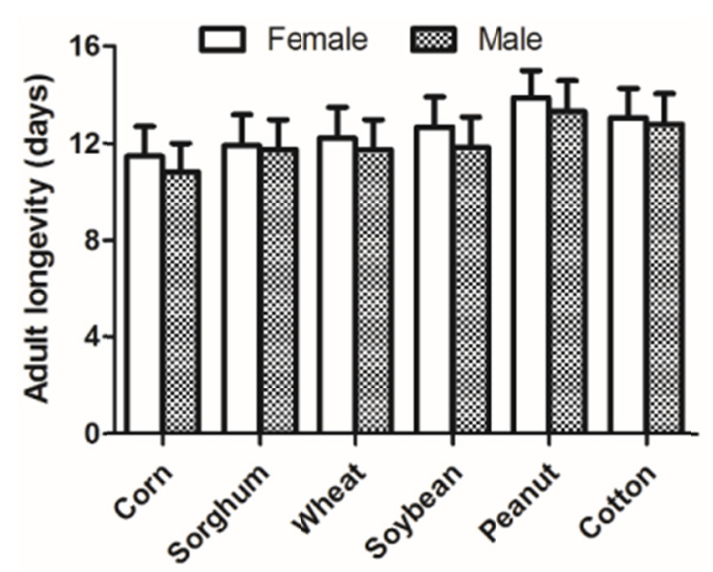

Figure 4. Female and male adult longevity (Mean $\pm \mathrm{SE}$ ) of Spodoptera frugiperda fed on six different host plants 


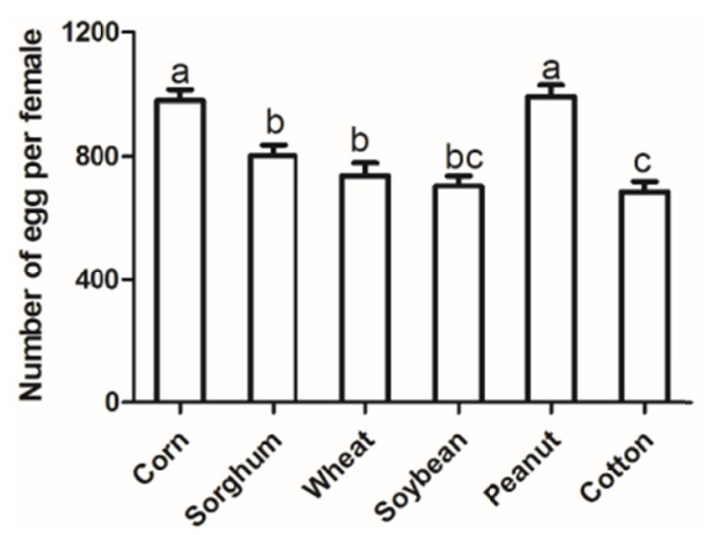

Figure 5. Number of eggs per female (Mean \pm SE) of Spodoptera frugiperda fed on six different host plants

\subsection{Food Intake, Utilization, Metabolization and Assimilation}

Host plant significantly affect food intake, utilization, metabolization and assimilation by $S$. frugiperda larvae. The weight gain $\left(F_{5,114}=10.43, P<0.001\right)$, food consumption $\left(F_{5,114}=22.18, P<0.001\right)$ and feces production $\left(F_{5,114}=29.92, P<0.001\right)$ of $S$. frugiperda larvae fed on grasses (corn, sorghum, and wheat) were significant higher than soybean and cotton (Figure 6).
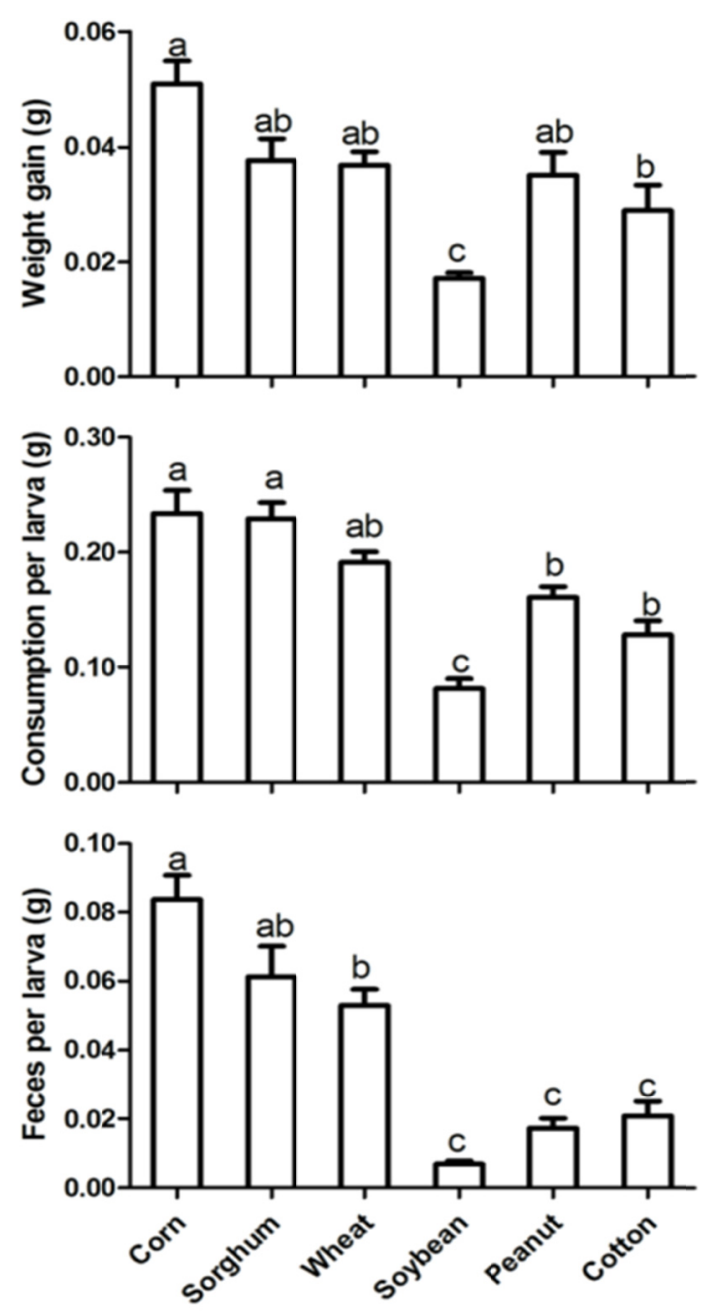

Figure 6. Mean ( \pm SE) of weight gain, consumption, and feces per larva by Spodoptera frugiperda fed on six host plants 
The food metabolized $\left(F_{5,114}=6.48, P<0.001\right)$ and assimilated $\left(F_{5,114}=10.06, P<0.001\right)$ by $S$. frugiperda larvae were significant different between host plants. Metabolized food per larva was the lowest (0.06 dry weight) when larvae were fed on soybean. Similarly, larvae assimilated less soybean leaves ( $0.08 \mathrm{~g}$ dry weight) than larvae fed on other host plants (Figure 7).
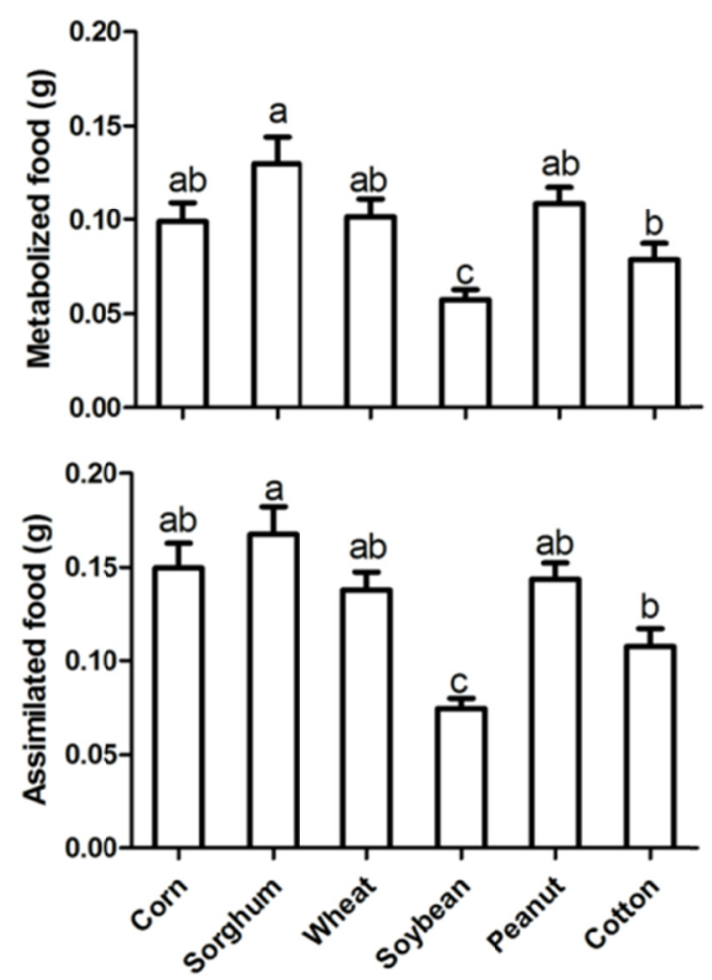

Figure 7. Mean ( $\pm \mathrm{SE})$ of food metabolized and assimilated of Spodoptera frugiperda larvae fed on six host plants

\subsection{Nutritional Indices}

The nutritional indices of $S$. frugiperda larvae were significantly influenced by host plants (Table $1, P<0.05$ in all cases). The values of RGR, RCR, RMR, ECI, and ECD were significantly higher in corn, peanut and sorghum, and lower in soybean and cotton. The highest value of $\mathrm{AD}$ was found in corn, which was $87.8 \%$, and the lowest value of $\mathrm{AD}$ was observed in heat, peanut and cotton, which was $84.3 \%, 84.6 \%$, and $84.9 \%$, respectively.

Table 1. Nutritional indices for Spodoptera frugiperda larvae fed on six host plants

\begin{tabular}{llllllll}
\hline \multirow{2}{*}{ Parameter } & \multicolumn{7}{c}{ Host plants } \\
\cline { 2 - 7 } & Corn & Sorghum & Wheat & Soybean & Peanut & Cotton & $F_{5,114}$ \\
\hline RGR(g/g/day) & $0.39 \pm 0.02 \mathrm{a}$ & $0.34 \pm 0.03 \mathrm{~b}$ & $0.32 \pm 0.02 \mathrm{bc}$ & $0.30 \pm 0.02 \mathrm{c}$ & $0.35 \pm 0.02 \mathrm{~b}$ & $0.29 \pm 0.03 \mathrm{c}$ & 2.65 \\
RCR(g/g/day) & $1.63 \pm 0.09 \mathrm{a}$ & $1.58 \pm 0.13 \mathrm{ab}$ & $1.52 \pm 0.11 \mathrm{ab}$ & $1.41 \pm 0.15 \mathrm{~b}$ & $1.60 \pm 0.17 \mathrm{a}$ & $1.38 \pm 0.13 \mathrm{~b}$ & 2.54 \\
RMR(g/g/day) & $1.08 \pm 0.12 \mathrm{ab}$ & $1.19 \pm 0.13 \mathrm{a}$ & $0.99 \pm 0.14 \mathrm{ab}$ & $0.73 \pm 0.06 \mathrm{~b}$ & $1.22 \pm 0.16 \mathrm{a}$ & $0.87 \pm 0.09 \mathrm{~b}$ & 3.02 \\
ECI (\%) & $23.62 \pm 1.86 \mathrm{a}$ & $21.53 \pm 2.01 \mathrm{ab}$ & $21.27 \pm 1.67 \mathrm{ab}$ & $20.85 \pm 1.36 \mathrm{~b}$ & $22.13 \pm 2.07 \mathrm{a}$ & $20.98 \pm 3.11 \mathrm{~b}$ & 2.26 \\
ECD (\%) & $26.91 \pm 2.72 \mathrm{a}$ & $25.09 \pm 1.61 \mathrm{ab}$ & $25.24 \pm 2.68 \mathrm{ab}$ & $24.13 \pm 3.69 \mathrm{~b}$ & $26.17 \pm 3.34 \mathrm{a}$ & $24.72 \pm 3.18 \mathrm{~b}$ & 2.84 \\
AD (\%) & $87.77 \pm 2.93 \mathrm{a}$ & $85.81 \pm 3.43 \mathrm{ab}$ & $84.27 \pm 2.64 \mathrm{~b}$ & $86.41 \pm 1.22 \mathrm{ab}$ & $84.56 \pm 1.56 \mathrm{~b}$ & $84.87 \pm 1.39 \mathrm{~b}$ & 27.93 \\
\hline
\end{tabular}

Note. All data are calculated in $\mathrm{g}$ dry weight.

Data in the table are represented as Mean \pm SE. Means in the same row followed by different letters are significantly different $(P<0.05)$. 


\section{Discussion}

The development of insects mainly depends on food quality (Barros et al., 2010). Therefore, the performance of insects are strongly influenced by the host plant (Bavaresco et al., 2004; Koussoroplis \& Wacker, 2016; McCormick et al., 2019). By comparing the biological characteristics, food consumption and utilization of $S$. frugiperda larvae fed on six different crops mainly cultivated in the mid-high latitude of China, significant differences were identified.

In the study, the development of $S$. frugiperda fed on corn was similar to the observations of Sharanabasappa et al. (2018), who reported that the larval period, pupal period, male adult longevity, female adult longevity, fecundity were 15.9 d, 10.5 d, 8.2 d, $10.8 \mathrm{~d}$ and 1064.8 eggs per female, respectively. S. frugiperda larvae reared on corn leaves exhibited a shorter developmental time in the larval and pupal stage, heavier pupal weight, and higher amounts of eggs per female than other tested plants. Our results were consistent with previous research that $S$. frugiperda larvae fed on corn performed better than on cotton or soybean (Buntin, 1986; Nagoshi et al., 2007). Compared to corn, S. frugiperda larvae fed on cotton and soybean were adversely affected with extended larval duration and reduced pupal weight (Silva et al., 2017).

Considering the plants tested, the number of eggs produced per female was significantly lower on cotton than corn and soybean. In contrast, the longevity of females reared on cotton was shorter than that of females reared on corn and soybean (Barros et al., 2010). In the present study, the fecundity of S. frugiperda fed on cotton was 683 eggs per female, significantly lower than that fed on corn, which was about 979 eggs per female. However, the longevity of females reared on cotton, corn and soybean was about $13.0 \mathrm{~d}, 11.9 \mathrm{~d}, 12.7 \mathrm{~d}$, respectively, which showed no significant differences between treatments.

The host plant significantly affected food consumption and utilization of $S$. frugiperda larvae. In the study, $S$. frugiperda larvae fed on soybean and cotton leaves had lower values of food consumption, feces production, and weight gain, together with lower values of RCR, RMR, RGR, and AD. This is probably due to decreased consumption of food, resulting in reduced production of feces and low weight gain, leading to the lower efficiency of food assimilation and subsequent conversion to body mass (Slansky \& Scriber, 1985; Giongo et al., 2015).

Among nutritional indices, ECI is the efficiency of an insect's ability to utilize the food ingested into growth, and ECD is the efficiency of conversion of digested food into growth (Nathan et al., 2005). Change in ECI and ECD reflects the conversion rates of food ingested and digested into body biomass (Abdel-Rahman \& Al-Mozini, 2007). In the present experiment, S. frugiperda larvae fed on cotton and soybean had lower values of ECI and ECD, which suggested that these larvae were unable to convert digested food into biomass efficiently. These findings indicated that cotton and soybean leaves were likely containing some toxic compounds that inhibit $S$. frugiperda's growth (Fite et al., 2018).

In the current experiment, S. frugiperda larvae fed on corn had higher nutritional indices than other hosts, which is consistent with the view of the previous study that corn could increase the consumption and nutrition of this pest (Pinto et al., 2019). The shorter larval and pupal period, the faster life cycle, the heavier pupal weight and the higher nutritional indices of S. frugiperda were recorded on corn compared to other host plants, indicating that corn was the most suitable host for S. frugiperda development. Studies of S. frugiperda populations showed that the crop-specific severity of $S$. frugiperda infestations is associated with host-related strains and, as a result, the corn is the preferred host plant for corn strain of S. frugiperda (Pashley et al., 1985; Meagher \& Nagoshi, 2004). Besides, this kind of plant might provide the best blend and balanced nutrition for insect development, including carbohydrates, amino acids, trace elements, fatty acids, vitamins, water, etc (Behmer, 2009).

The lower performance of $S$. frugiperda larvae feeding on cotton and soybean leaves have some possible explanation. Secondary compounds in cotton leaves, such as gossypol that confers resistance to herbivores, slows the development of larvae and reduces weight gain (Montandon et al., 1987; Farrar \& Ridgway, 2000; Hoover et al., 2000). Soybean has inducible phytoalexin glyceollin, which plays a role in insect resistance. These toxic substances posed an antifedent activity against the specific herbivorous insect. The plant protected itself against pests by creating a toxic environment at the cellular level (Fischer et al., 1990). An extended duration of the larval phase is considered as a compensatory strategy when food is not suitable for their development so that they remain a more extended period feeding to form active pupae and adults (Smith \& Collier, 2005).

Likewise, nutritional indices also used to study ingestion, digestion, assimilation, and food conversion of other Lepidopteran larvae, such as Helicoverpa armigera (Naseri et al., 2010; Fite et al., 2018; Truzi et al., 2019). Although the nutritional parameter varied in different species, larval instars, and feeding times, it was crucial to determine the fitness of insects. The development, survival and fecundity of the insect were affected by the 
different nutritive values of crops which could influence the immigration, emigration, even population dynamics of the target insect pest. Therefore, knowledge of nutritional indices in conjunction with biological studies may contribute to an understanding of the physiological basis of insect response to host plants, which is essential for the development of integrated pest management programs.

\section{Conclusions}

In conclusion, S. frugiperda was able to develop and reproduce on all six host plants. Biology and nutritional indexes suggested that corn was the most suitable host. Besides, peanut, sorghum and wheat have also been shown to be the appropriate host species for growth and development of S. frugiperda. Although cotton and soybean were found to be less adequate, high larvae and pupal survivors recorded on cotton and soybean leaves have indicated that damage could also occur in these plants. Future work should focus on the long-term interaction and evolution between the pest and plant, such as the plant suitability and/or resistance to the target insect pest. Further data collection from different sites would help to estimate the host range, potential economic losses and design an effective pest management strategies for $S$. frugiperda.

\section{Acknowledgements}

This work was supported by the National Key R\&D Program of China (2019YFD0300101). The Agricultural Science and Technology Innovation Program (CAAS-ZDRW202007) and China Agriculture Research System (CARS-02). We thank Dr. Siva Prasath for helping with language correction.

\section{References}

Abdel-Rahman, H. R., \& Al-Mozini, R. N. (2007). Antifeedant and toxic activity of some plant extracts against larvae of cotton leafworm Spodoptera littoralis (Lepidoptera: Noctuidae). Pak J Biol Sci, 10(24), 4467-4472. https://10.3923/pjbs.2007.4467.4472

Barcelos, L. M., Fernandes, F. O., Lopes, C., Emygdio, B. M., Valgas, R., de Carvalho, I. F., \& da Rosa, A. P. S. (2019). Biology and nutritional indexes of Spodoptera frugiperda (Lepidoptera: Noctuidae) in saccharine sorghum. Journal of Agricultural Science, 11(4), 126-135. https://doi.org/10.5539/jas.v11n4p126

Barros, E. M., Torres, J. B., Ruberson, J. R., \& Oliveira, M. D. (2010). Development of Spodoptera frugiperda on different hosts and damage to reproductive structures in cotton. Entomologia Experimentalis et Applicata, 137(3), 237-245. https://doi.org/10.1111/j.1570-7458.2010.01058.x

Bavaresco, A., Garcia, M. S., Grützmacher, A. D., Ringenberg, R., \& Foresti, J. (2004). Adequação de uma dieta artificial para a criação de Spodoptera cosmioides (Walk.) (Lepidoptera: Noctuidae) em laboratório. Neotropical Entomology, 33(2), 155-161. https://doi.org/10.1590/S1519-566X2004000200005

Behmer, S. T. (2009). Insect herbivore nutrient regulation. Annual Review of Entomology, 54, 165-187. https://doi.org/10.1146/annurev.ento.54.110807.090537

Bueno, R. C., Moscardi, F., Parra, J. R., \& Hoffmann-Campo, C. B. (2011). Lepidopteran larva consumption of soybean foliage: basis for developing multiple-species economic thresholds for pest management decisions. Pest Management Science, 67(2), 170-174. https://doi.org/10.1002/ps.2047

Buntin, G. D. (1986). A review of plant response to fall armyworm, Spodoptera frugiperda (J.E. Smith), injury in selected field and forage crops. Florida Entomologist, 69(3), 549-559. https://doi.org/10.2307/3495389

Busato, G. R., Grützmacher, A. D., Garcia, M. S., Giolo, F. P., \& Martins, A. F. (2002). Consumo e utilização de alimento por Spodoptera frugiperda (J.E. Smith) (Lepidoptera: Noctuidae) originária de diferentes regiões do Rio Grande do Sul, das culturas do milho e do arroz irrigado. Neotropical Entomology, 31(4), 525-529. https://doi.org/10.1590/S1519-566X2002000400003

Clark, P. L., Molina-Ochoa, J., Martinelli, S., Skoda, S. R., Isenhour, D. J., Lee, D. J., ... Foster, J. E. (2007). Population variation of the fall armyworm, Spodoptera frugiperda, in the Western Hemisphere. Journal of Insect Science, 7(1). https://doi.org/10.1673/031.007.0501

Day, R., Abrahams, P., Bateman, M., Beale, T., Clottey, V., Cock, M., ... Godwin, J. (2017). Fall armyworm: impacts and implications for Africa. Outlooks on Pest Management, 28(5), 196-201. https://doi.org/ 10.1564/v28_oct_02

Farrar, R. R., \& Ridgway, R. L. (2000). Host plant effects on the activity of selected nuclear polyhedrosis viruses against the corn earworm and beet armyworm (Lepidoptera: Noctuidae). Environmental Entomology, 29(1), 108-115. https://doi.org/10.1603/0046-225X-29.1.108 
Fischer, D. C., Kogan, M., \& Paxton, J. (1990). Effect of glyceollin, a soybean phytoalexin, on feeding by three phytophagous beetles (Coleoptera: Coccinellidae and Chrysomelidae): Dose versus response. Environmental Entomology, 19(5), 1278-1282. https://doi.org/10.1093/ee/19.5.1278

Fite, T., Tefera, T., Negeri, M., Damte, T., \& Sori, W. (2018) Management of Helicoverpa armigera (Lepidoptera: Noctuidae) by nutritional indices and botanical extracts of Millettia ferruginea and Azadirachta indica. Advances in Entomology, 6, 235-255. https://doi.org/10.4236/ae.2018.64019.

Giongo, A. M. M. V., Freitas, J. D., Freitas, S. D. L., \& Silva, M. F. G. F. (2015). Growth and nutritional physiology of Spodoptera frugiperda (Lepidoptera: Noctuidae) fed on Meliaceae fractions. Revista Colombiana de Entomología, 41(1), 33-40. http:/www.scielo.org.co/scielo.php?script=sci_arttext\&pid=S0 120-04882015000100006\&lng=en\&nrm=iso\&tlng=en

Goergen, G., Kumar, P. L., Sankung, S. B., Togola, A., \& Tamò, M. (2016). First report of outbreaks of the fall armyworm Spodoptera frugiperda (J. E. Smith) (Lepidoptera, Noctuidae), a new alien invasive pest in West and Central Africa. Plos One, 11(10). https://doi.org/10.1371/journal.pone.0165632

Guo, J. F., Zhang, M. D., Gao, Z. P., Wang, D. J., He, K. L., \& Wang, Z. Y. (2020). Comparison of larval performance and oviposition preference of Spodoptera frugiperda among three host plants: Potential risks to potato and tobacco crops. Insect Science. https://doi.org/10.1111/1744-7917.12830

Guo, J. F., Zhao, J., He, K. L., Zhang, F., \& Wang, Z. Y. (2018). Potential invasion of the crop-devastating insect pest fall armyworm Spodoptera frugiperda to China. Plant Protection, 44(6), 1-10. https://doi.org/ 10.16688/ j.zwbh.2018452

Hemati, S., Naseri, B., Nouri Ganbalani, G., Rafiee Dastjerdi, H., \& Golizadeh, A. (2020). Effect of different host plants on nutritional indices of the pod borer, Helicoverpa armigera. Journal of Insect Science, 12(55), 1-15. https://doi.org/10.1673/031.012.5501

Hoover, K., Washburn, J. O., \& Volkman, L. E. (2000). Midgut-based resistance of Heliothis virescens to baculovirus infection mediated by phytochemicals in cotton. Journal of Insect Physiology, 46(6), 999-1007. https://doi.org/10.1016/S0022-1910(99)00211-5

House, H. (1961). Insect nutrition. Annual Review of Entomology, 6(1), 13-26. https://doi.org/10.1146/annurev. en.06.010161.000305

Jiang, Y., Liu, J., Xie, M., Li, Y., Yang, J., Zhang, M., \& Qiu, K. (2019). Observation on law of diffusion damage of Spodoptera frugiperda in China in 2019. Plant Protection, 45(6), 10-19. https://doi.org/10.16688/j.zwbh.2019539

Jing, D. P., Guo, J. F., Jiang, Y. Y., Zhao, J. Z., Sethi, A., He, K. L., \& Wang, Z. Y. (2020). Initial detections and spread of invasive Spodoptera frugiperda in China and comparisons with other noctuid larvae in cornfields using molecular techniques. Insect Science, 27(4), 780-790. https://doi.org/10.1111/1744-7917.12700

Kolmogorov, A. (1933). Sulla determinazione empirica di una legge di distribuzione. Giornale dell'Istituto Italiano degli Attuari, 4, 83-91.

Koussoroplis, A. M., \& Wacker, A. (2016). Covariance modulates the effect of joint temperature and food variance on ectotherm life-history traits. Ecology Letters, 19(2), 143-152. https://doi.org/10.1111/ele.12546

Levene, H. (1960). Contributions to probability and statistics. Essays in honor of Harold Hotelling, 278-292.

Li, X. J., Wu, M. F., Ma, J., Gao, B. Y., Wu, Q. L., Chen, A. D., ... Early, R. (2020). Prediction of migratory routes of the invasive fall armyworm in eastern China using a trajectory analytical approach. Pest Management Science, 76(2), 454-463. https://doi.org/10.1002/ps.5530

Lima, M. S., Silva, P. S. L., Oliveira, O. F., Silva, K. M. B., \& Freitas, F. C. L. (2010) Corn yield response to weed and fall armyworm controls. Planta Daninha, 28, 103-111. https://doi.org/10.1590/S0100-835820100 00100013

McCormick, A. C., Arrigo, L., Eggenberger, H., Mescher, M. C., \& De Moraes, C. M. (2019). Divergent behavioural responses of gypsy moth (Lymantria dispar) caterpillars from three different subspecies to potential host trees. Scientific Reports, 9(1), 1-12. https:// doi.org/10.1038/s41598-019-45201-3

Meagher, R. L., \& Nagoshi, R. N. (2004). Population dynamics and occurrence of Spodoptera frugiperda host strains in southern Florida. Ecological Entomology, 29(5), 614-620. https://doi.org/10.1111/j.0307-6946. 2004.00629.x 
Montandon, R., Stipanovic, R., Williams, H., Sterling, W., \& Vinson, S. (1987). Nutritional indices and excretion of gossypol by Alabama argillacea (Hübner) and Heliothis virescens (F.) (Lepidoptera: Noctuidae) fed glanded and glandless cotyledonary cotton leaves. Journal of Economic Entomology, 80(1), 32-36. https://doi.org/10.1093/jee/80.1.32

Montezano, D. G., Specht, A., Sosa-Gómez, D. R., Roque-Specht, V. F., Sousa-Silva, J. C., Paula-Moraes, S. D., ... Hunt, T. (2018). Host plants of Spodoptera frugiperda (Lepidoptera: Noctuidae) in the Americas. African Entomology, 26(2), 286-300. https://doi.org/10.4001/003.026.0286

Nagoshi, R. N. (2009). Can the amount of corn acreage predict fall armyworm (Lepidoptera: Noctuidae) infestation levels in nearby cotton? Journal of Economic Entomology, 102(1), 210-218. https://doi.org/ $10.1603 / 029.102 .0130$

Nagoshi, R. N., \& Meagher, R. L. (2004). Seasonal distribution of fall armyworm (Lepidoptera: Noctuidae) host strains in agricultural and turf grass habitats. Environmental Entomology, 33(4), 881-889. https://doi.org/ $10.1603 / 0046-225 \mathrm{x}-33.4 .881$

Nagoshi, R. N., Adamczyk, J. J., Meagher, R. L., Gore, J., \& Jackson, R. (2007). Using stable isotope analysis to examine fall armyworm (Lepidoptera: Noctuidae) host strains in a cotton habitat. Journal of Economic Entomology, 100(5), 1569-1576. https://doi.org/10.1093/jee/100.5.1569

Nagoshi, R. N., Goergen, G., Tounou, K. A., Agboka, K., Koffi, D., \& Meagher, R. L. (2018). Analysis of strain distribution, migratory potential, and invasion history of fall armyworm populations in northern Sub-Saharan Africa. Scientific Reports, 8(1), 1-10. https://doi.org/10.1038/s41598-018-21954-1

Nagoshi, R. N., Koffi, D., Agboka, K., Tounou, K. A., Banerjee, R., Jurat-Fuentes, J. L., \& Meagher, R. L. (2017). Comparative molecular analyses of invasive fall armyworm in Togo reveal strong similarities to populations from the eastern United States and the Greater Antilles. Plos One, 12(7). https://doi.org/ 10.1371/journal.pone.0181982

Naseri, B., Fathipour, Y., Moharramipour, S., \& Hosseininaveh, V. (2010). Nutritional indices of the cotton bollworm, Helicoverpa armigera, on 13 soybean varieties. Journal of Insect Science, 10(1), 151. https://doi.org/10.1673/031.010.14111

Nathan, S. S., Chung, P. G., \& Murugan, K. (2005). Effect of biopesticides applied separately or together on nutritional indices of the rice leaf folder Cnaphalocrocis medinalis. Phytoparasitica, 33(2), 187-195. https://doi.org/10.1007/BF03029978

Pashley, D. P., Johnson, S. J., \& Sparks, A. N. (1985). Genetic population structure of migratory moths: The fall armyworm (Lepidoptera: Noctuidae). Annals of the Entomological Society of America, 78(6), 756-762. https://doi.org/10.1093/aesa/78.6.756

Pinto, J. R. L., Torres, A. F., Truzi, C. C., Vieira, N. F., Vacari, A. M., \& De Bortoli, S. A. (2019). Artificial corn-based diet for rearing Spodoptera frugiperda (Lepidoptera: Noctuidae). Journal of Insect Science, 19(4), 2. https://doi.org/10.1093/jisesa/iez052

Quisenberry, S. S. (1991). Fall armyworm (Lepidoptera: Noctuidae) host strain reproductive compatibility. The Florida Entomologist, 74(2), 194-199. https://doi.org/10.2307/3495297

Ramalho, F., Malaquias, J., da Silva, C., \& Zanuncio, J. (2011). Feeding of fall armyworm, Spodoptera frugiperda, on Bt transgenic cotton and its isoline. Entomologia Experimentalis Et Applicata, 139(3), 207-214. https://10.1111/j.1570-7458.2011.01121.x

Rosa-Cancino, W., Rojas, J., Cruz-Lopez, L., Castillo, A., \& Malo, E. (2016). Attraction, feeding preference, and performance of Spodoptera frugiperda larvae (Lepidoptera: Noctuidae) reared on two varieties of maize. Environmental Entomology, 45(2), 384-389. https://doi.org/10.1093/ee/nvv229

Scriber, J., \& Slansky , J. (1981). The nutritional ecology of immature insects. Annual review of entomology, 26(1), 183-211. https://doi.org/10.1146/annurev.en.26.010181.001151

Sharanabasappa, Kalleshwaraswamy, C., Maruthi, M., \& Pavithra, H. (2018). Biology of invasive fall army worm Spodoptera frugiperda (J.E. Smith) (Lepidoptera: Noctuidae) on maize. Indian Journal of Entomology, 80(3), 540-543. https://doi.org/10.5958/0974-8172.2018.00238.9

Silva, D. M. D., Bueno, A. D. F., Andrade, K., Stecca, C. D. S., Neves, P. M. O. J., \& Oliveira, M. C. N. D. (2017). Biology and nutrition of Spodoptera frugiperda (Lepidoptera: Noctuidae) fed on different food sources. Scientia Agricola, 74(1), 18-31. https://doi.org/10.1590/1678-992x-2015-0160 
Slansky, F. (1990). Insect nutritional ecology as a basis for studying host plant resistance. The Florida Entomologist, 73(3), 359-378. https://doi.org/10.2307/3495455

Slansky, J., \& Scriber, J. (1985). Food consumption and utilization. In G. A. Kerkut, \& L. I. Gilbert (Eds.), Comprehensive Insect Physiology, Biochemistry, and Pharmacology (pp. 87-163). Pergamon Press.

Smirnov, N. V. (1939). On the estimation of the discrepancy between empirical curves of distribution for two independent samples. Moscow University Mathematics Bulletin, 2(2), 3-14.

Smith, B. J., \& Collier, K. J. (2005). Tolerances to diurnally varying temperature for three species of adult aquatic insects from New Zealand. Environmental Entomology, 34(4), 748-754. https://doi.org/10.1603/ 0046-225X-34.4.748

Sousa, F. F., Mendes, S. M., Santos-Amaya, O. F., Araújo, O. G., Oliveira, E. E., \& Pereira, E. J. G. (2016). Life-History traits of Spodoptera frugiperda populations exposed to low-dose Bt maize. Plos One, 11(5). https://doi.org/10.1371/journal.pone.0156608

Souza, A. M., Ávila, C. J., \& Parra, J. R. (2001). Food intake and utilization by Diatraea saccharalis (Fabr.) (Lepidoptera: Pyralidae), Heliothis virescens (Fabr.) and Spodoptera frugiperda (J.E. Smith) (Lepidoptera: Noctuidae) at two different temperatures. Neotropical Entomology, 30(1), 11-17. https://doi.org/ $10.1590 /$ S1519-566X2001000100003

Sparks, A. N. (1979). Fall armyworm symposium: A review of the biology of the fall armyworm. Florida Entomologist, 62(2), 82-87. https://www.jstor.org/stable/3494083

Sun, X., Hu, C., Jia, H., Wu, Q., Shen, X., Zhao, S., Jiang, Y., \& Wu, K. (2019). Case study on the first immigration of fall armyworm Spodoptera frugiperda invading into China. Journal of Integrative Agriculture, 18, 2-10. https://doi.org/10.1016/S2095-3119(19)62839-X

Truzi, C. C., Holzhausen, H. G., Álvaro, J. C., De Laurentis, V. L., Vieira, N. F., Vacari, A. M., \& De Bortoli, S. A. (2019). Food consumption utilization, and life history parameters of Helicoverpa armigera (Lepidoptera: Noctuidae) reared on diets of varying protein level. Journal of Insect Science, 19(1), 12. https://doi.org/ 10.1093/jisesa/iey138

Waldbauer, G. P. (1968). The consumption and utilization of food by insects. In J. W. L. Beament, J. E. Treherne \& V. B. Wigglesworth (Eds.), Advances in Insect Physiology (pp. 229-288): Academic Press

Zhao, F., Zhang, W., Hoffmann, A. A., \& Ma, C. S. (2014). Night warming on hot days produces novel impacts on development, survival and reproduction in a small arthropod. Journal of Animal Ecology, 83, 769-778. https://doi.org/10.1111/1365-2656.12196

\section{Copyrights}

Copyright for this article is retained by the author(s), with first publication rights granted to the journal.

This is an open-access article distributed under the terms and conditions of the Creative Commons Attribution license (http://creativecommons.org/licenses/by/4.0/). 